\title{
DIE TOEPASSING VAN DIDAKTIESE BEGINSELS IN DIE
}

\section{ONDERWYSPRAKTYK*}

In hierdie voordrag gaan dit by uitstek om drie sake, met nadere kwalifiseringe. Hierdie sake is:

1. Die terrein van die didaktiek.

2. Die normatiewe karakter van die didaktiek.

3. Die praktiese aanwendbaarheid van didaktiese beginsels in die onderwyspraktyk. By wyse van toeligting sal daar dan kortliks na gedifferensieerde onderwys verwys word.

\section{Die terrein van die didaktiek}

(a) Die begrip didaktiek

Net soos die Griekse woord paidagogia kinderleiding beteken ( paid-, stam van pais: kind en agein: leiding of om te laat handel; paid- en agein: om 'n kind te lei of hom die weg aan te wys)') maar geleidelik in meer geestelike sin uitgebrei het tot pedagogie (opvoedkuns), wat met verloop van tyd weer ontwikkel het tot pedagogiek (opvoedkunde), so het die begrip didaktiek 'n lang ontwikkelingsgeskiedenis.

Etimologies kan die woord didaktiek teruggevoer word tot die Ariese wortel waarvan die werkwoord "da" beteken om uit te deel, of om te gee, of om te onderrig. Uit hierdie Ariese wortel ontstaan die Griekse werkwoord didaskein (om te onderrig of af te rig) en die afgeleide byvoeglike naamwoord didaktikos (leerryk) ${ }^{2}$ )

Gedurende die tyd van Comenius is die woord didaktiek eintlik vir die eerste keer as vakterm gebruik en deur hom beskryf as die kuns om onderrig te gee. ${ }^{3}$ ) Didaktiek word dus 'n onderwyskuns.

Maar net soos pedagogie (opvoedkuns) in die loop van tyd ontwikkel het tot pedagogiek (opvoedkunde), so ook het die didaktiek uiteindelik 'n kunde geword wat op wetenskaplike gronde berus.

* Inougurele rede gehou by die aanvaarding van 'n ere-professoraat in die Opvoedkunde aan die P.U. vir C.H.O., op 30 April 1965, deur prof. dr. J. H. Jooste. 
Die ontwikkeling van die kinderpsigologie en die ontdekking van wetmatighede van psigiese funksies (byvoorbeeld geheue en denke) het aanleiding gegee tot die toepassing van wetenskaplike gegewens in die didaktiek. Die selfstandige karakter van die didaktiek is hierdeur aangetas en die gevaar het ontstaan dat didaktiek 'n hulpwetenskap van die psigologie sou word.4) Nadere besinning oor die opvoedingsverskynsel waarmee ons in die praktyk gekonfronteer staan, het egter tot die besef gelei dat die konkrete onderwyssituasie die uitgangspunt vir alle didaktiese ondersoek moet wees. Vir die didaktiek as kuns neem die persoonlikheid van die onderwyser, sy toewyding, sy oorspronklikheid en sy geesdrif die vernaamste plek in. Die didaktiek as wetenskap rig die aandag egter op 'n analise van die leerproses, op die sistematisering van die didaktiese beginsels, op die ordening van die leerstof en op die vorming van leersituasies. ${ }^{5}$ )

Didaktiek is dus nie net onderwyskuns nie maar onderwyskunde.

Ons sal poog om die deurwerking van die teoretiese beginsels van hierdie wetenskap in die onderwyspraktyk aan die hand van enkele voorbeelde nader toe te lig. Hierdie riglyne het vanselfsprekend betrekking op die hele veld van die didaktiese arbeid in die skool, wat onder die volgende didaktiese beginsels saamgevat kan word:

(i) Die vormingsprinsipe (d.w.s. die leerproses in sy gerigtheid op die vormingsdoel).

(ii) Die ontwikkelingsprinsipe (die leerplan of kurrikulum). (iii) Die hanteringsprinsipe (die leervorm).

Dit is egter nodig dat ons eers kortliks verwys na die verband tussen didaktiek en pedagogiek, en na die normatiewe karakter van die didaktiese pedagogiek ten einde te wys op die innige vervlegtheid van onderwyspraktyk, onderwysteorie en lewensopvatting.

\section{(b) Die verband tussen didaktiek en pedagogiek}

Die hele leerproses in die skool kan beskryf word as ' $n$ ontmoeting van die kind met die kultuur, d.w.s. met die wêreld van norme en gedragsisteme, die taalwêreld, die getallewêreld en die mens se interpretasie van die wêreld van ruimte en tyd. Die leerproses word nou daarop gerig om die kind op 'n doeltreffende manier met hierdie vormsisteme te 
konfronteer sodat hy dit deur kennis en belewing sy eie kan maak en daardeur gevorm kan word.

In die skoolse didaktiese situasie, soos in die pedagogiese situasie, hou 'n volwassene hom besig met 'n kind. In die didaktiese situasie is die onderwyser ook steungewer en hulpverlener. Daar is derhalwe ook sprake van 'n leermoment van ontmoeting; trouens, die moontlikheid bestaan dat die samesyn om te leer momenteel kan oorgaan in 'n ontmoeting met die opdrag as opgawe, die verantwoordbare handeling as doelstelling en die kapasiteite van die persoon as realiseringsmiddele. Die didaktiese moment is meteens opvoedingsmoment. $\left.{ }^{6}\right)$ Dit volg dat beide die wyse waarop en die doel waarmee die volwassene hom besig hou met 'n kind, bepaal word deur die volwassene se ,idee" van die kind.

In die mens-mens-omgangsituasie ontstaan 'n handelingsituasie. Hierdie handelingsituasie kan oorgaan in 'n opvoedingshandeling wat opsetlik of onopsetlik kan wees. Ter verwesenliking van sy doel skakel die onderwyser opsetlike handelinge in die opvoedingsituasie in.

Hierdie opsetlike handelinge moet as voorafbeplande middele vir die verwesenliking van sy opvoedingsdoel gesien word. Die wetenskap, of ook hulpwetenskap van die teoretiese pedagogiek ,wat met die bedenking, beplanning en sistematisering van die opvoedingsmiddele as opvoedingshandelinge te doen het noem ons didaktiek, die onderwysleer of liefs die didaktiese pedagogiek".?)

\section{Die normatiewe karakter van die didaktiese pedagogiek}

Didaktiek as die leer insake die sistematiese oordrag van kennis en kunde is as ' $n$ leer dus 'n teorie. Hoewel onskeibaar van die pedagogiek berus hierdie teorie op empiriese gronde wat uit die ervaring deur die denke opgebou word. ${ }^{8}$ ) Ons tref beide teoretiese en praktiese momente in die didaktiek aan. Dit sluit besinning oor wat gedoen kan word en bepeinsing oor moontlike verbeteringe daarvan in, maar dit het ook betrekking op die toepassing daarvan en die daadwerklike pogings om beter resultate te verkry. Die didaktiek is dus 'n vooruitloop op die praktyk maar ook 'n agternaloop van die praktyk.

Die didaktiek is 'n praktiese wetenskap wat t.o.v. die praktiese momente net so "teoreties" is as 'n teoretiese wetenskap 
in soverre dit naamlik ,beskou”. As praktiese wetenskap besin die didaktiek egter nie alleen oor hoe dinge is nie, maar ook oor hoe daar gehandel moet word om die doel te verwesenlik. Dit gaan dus ook om die omstandighede wat vir hierdie verwesenliking nodig is. Hiersonder sou die didaktiek trouens handel oor 'n ,leerling" wat geen kind, 'n „leraar" wat geen mens en ,leerstof" wat geen deel uitmaak van 'n geestelike kultuurgeheel nie.

Ons vind in die praktyk juis dat die oorbeklemtoning van "hoe" dinge is, m.a.w. die onoordeelkundige toepassing van resultate van eksperimentele ondersoek uit die psigologie en meer in besonder die pedologie, tot oorverpsigologisering en oorverdidaktisering van ons onderwys lei,?) soms met uiters nadelige gevolge.

Die nuwe koers of wending, naamlik die benadering van die mens in sy volle eksistensiële verband van menswees as persoonwees, wat meer as net verfrissing en vernuwing (Kohnstamm) teweeggebring het, en die lig skerp laat val op 'n heel nuwe benaderingswyse (Buytendijk), waardeur die mens gesien word as diegene wat ontmoet en ontmoet word (Van den Berg), het veel bygedra tot die grondslae van die nuwe didaktiek. Hierdie nuwere didaktiek gaan uit van die „eie wêreld van die kind", 'n wêreld wat geken en aktief beleef moet word. Die lewe van die kind word dan gesien as 'n getuienis van sy ontdekking van die wêreld waarmee hy gekonfronteer word.

Die kind se ontdekking van die wêreld mag egter nie bloot willekeurig geskied en deur sy momentele belangstellings alleen gerig word nie; dit vra ook na vastheid, bepaaldheid en vormgewing. Hy moet deur die volwassene gelei word om die vormsisteme van die wêreld van die volwassene te ken en te beleef. Daaruit moet hy dan in toenemende mate sy keuse doen. Dié vormsisteme wat hy as waardevol aanvaar, sal dan in sy eie lewe daadwerklik funksioneer en in toenemende mate daaraan gestalte verleen.

Dit volg dat ons didaktiese handeling nie los kan staan van ons algemene opvoedingsdoel nie, maar dat dit juis beoog om die pedagogiese doelstellings deur die harmoniese opbou en vorming van die leerling in die skoollewe te verwerklik.

Hierdie stellingname is in lyn met die wat prof. Schutte ${ }^{10}$ ) in ooreenstemming met prof. Coetzee ${ }^{11}$ ) soos volg t.o.v. die Empiriese Opvoedkunde stel: 
„Die Empiriese Opvoedkunde is geen normatiewe wetenskap nie, maar 'n feitewetenskap. So eenvoudig is dit egter nie want... selfs die empiries-gevonde gegewens in die Opvoedkunde is nooit wiskundig-eksak nie; selfs die syfers word verskillend verstaan vanuit verskillende standpunte". Of, soos prof. Bingle ${ }^{12}$ ) dit stel: „Die kind ontwikkel - die terrein van die sielkunde - soos hy grootgemaak word - die terrein van die opvoedkunde; dit is nie dat die kind ontwikkel en dat hy grootgemaak en dat hy opgevoed word nie... die kind se ontwikkeling staan dus nie buite sy opvoeding nie... Dit bestaan eerder in die vorming van sy ontwikkeling gelyktydig met die beïnvloeding van sy rypwording".

Die didaktiek is nie bloot deskriptief nie, maar ook normatief; ${ }^{13}$ ) dit bepaal nie net die feitelike inhoud van die onderwys nie, maar is ook begaan oor die waardes wat in daardie inhoud verskuil lê.

Dat die doel van die opvoeding, en daarmee saam die onderwyspraktyk, deur die lewensopvatting van die opvoeder bepaal word, is 'n wyd aanvaarde feit. Trouens, die opvoedingsdoel word bepaal deur die lewensdoel. Die opvoeder se idee i.v.m. die lewe bepaal sy visie oor die opvoeding. Die prinsipiële opvoedkunde, wat as teoretiese besinning onlosmaaklik met waardes en waardefilosofie gemoeid is, is dus bepalend vir die opvoeding as praktyk waardeur die opvoeder aan ' $n$ bepaalde lewensopvatting gestalte wil gee.

Die lewensopvatting, gesien as totaal van die denkbeelde oor die lewenswaardevolle as die lewensverpligtende en die mensopeisende, bevat 'n uitgesproke "verpligtingskarakter" met behoorlikheidsmomente wat normerende invloed het op alles wat die mens doen, ${ }^{14}$ ) en dit oorspan die hele terrein van ons didaktiese arbeid.

Met hierdie stellingname t.o.v. die verband tussen lewensopvatting, didaktiek en pedagogiek kan ons nou na enkele praktiese toepassings van didaktiese-pedagogiese beginsels in in die onderwyspraktyk verwys.

3. Die praktiese aanwendbaarheid van didakties-pedagogiese beginsels

Ons stel ons ten doel om ons bespreking in hoofsaak tot enkele didaktiese beginsels, d.u.s. tot enkele voorbeelde van die formele en organiseerbare opvoedingsmomente, te beperk.

Dat die didaktiese voorskrif, wat in die didaktiese situasie 
op die vormingsprinsipe, die ontwikkelingsprinsipe en die hanteringsprinsipe gefundeer is, ten nouste saamhang met die mees fundementele algemeen-pedagogiese problematiek, sal egter telkens blyk as ons voorts agtereenvolgens na hierdie drie prinsipes verwys.

\section{(a) T.o.v. die vormingsprinsipe}

Die vormingsprinsipe hou in dat die onderwys as geheel gerig moet wees op die harmoniese ontwikkeling van die persoonlikheid van die kind.

Juis in die vormingsprinsipe (d.w.s. die leerproses in sy gerigtheid op die vormingsdoel) word die pedagogiese weer sentraal gestel in die didaktiese handeling. Dit volg dan ook vanself dat die opvoeder 'n groot verantwoordelikheid dra teenoor die opvoedeling, wat enersyds teen homself beskerm moet word, sodat hy andersyds tot volle menslikheid kan ontwikkel.

Die opvoedingsdaad word deur die voluassene geïnisieer met die oog op 'n anders-wees, maar dit is nie sonder meer 'n gedwonge anders-word nie, want opvoeding is steungewing tot verantwoordelikheidsaanvaarding en as sodanig bewusmaking van behoorlikheidseise wat die mens uiteindelik as gewetenseise aanspreek..$^{15}$ )

'n Onvolwasse, onselfstandige, onverantwoordelike onderwyser kan hierdie taak nie onderneem nie. Die onderwyser wat self nie glo in sy bemoeienis met die kind nie, sal enersyds nie die vertroue en medeverantwoordelikheid van die kind vir sy grootmaking wek nie, en andersyds sal sy werksaamheid mank gaan aan die onberekenbare stukrag wat vertroue in die kind aan sy werk kan verleen.

Dit is juis die liefde en toewyding van die opvoeder wat die geloof van die kind in die gesag van die norme wat deur die opvoeder eerbiedig word, wek en versterk. Wie nie die opvoedingsverantwoordelikheid as 'n opdrag met volle oorgawe, toeuyding en blymoedigheid aanvaar nie, kan nie die kind ontmoet nie, eenvoudig omdat hy die kind nie aanvaar nie. $\left.{ }^{16}\right)$ In die ontmoeting van persoon met persoon, in besonder in die opvoedingsituasie, kry ons die edelste vergestalting van die bestrewing van menswees as die opvoeder die gesag van die grootste Opvoeder, Jesus Christus, aanvaar het. Sy aanvaar- 
ding van afhanklikheid verseker dan sy grootste selfstandigheid, want dan word die mens wat hy behoort te wees: Kind van God. Hier is die grense van alle wetenskap oorskry en staan die mens voor die misterie van die ondeurgrondelike Liefde wat die liefde onder mense ook moontlik maak. ${ }^{17}$ ) Die vormende invloed van die Christen is anders as die van die ongelowige.

(b) T.o.v. die ontwikkelingsprinsipe (die leerplan of kurrikulum)

Die teologies georiënteerde beskouing van die mens met sy oorsprong as skepsel van God, sy wese na die beeld van God, al is dit deur die sonde verduister, en sy bestemming in God, hou vir diegene wat dit as geopenbaarde waarhede in die geloof aanvaar, iets van 'n oneindige ryke en diepe betekenis in.

Die opvoeder met hierdie lewensopvatting aanvaar dit dan ook as vereiste vir sy opvoedingsbemoeienis dat hierdie beskouing tot al die lewensterreine sal deurdring. En vir hierdie deurwerking van die prinsipiële na die praktiese is 'n grondige kennis van pedagogies-didaktiese beginsels 'n vereiste. Dit sluit kennis van die leerling en kennis van die leerstof in, maar verder o.a. ook die verband tussen die twee in byvoorbeeld 'n gedifferensieerde onderwysprogram.

Die wese van gedifferensieerde onderwys in enige formele onderwysprogram lê juis in die doelbewuste en doelgerigte konfrontering van leerlinge met fundamentele ordeningsmiddels en oplossingsmetodes op so 'n wyse dat dit ooreenstem met die kind se besondere begaafdheidstruktuur.

In hierdie verband verwys ons voorts kortliks na die verband tussen lewensopvatting en kurrikulumsamestelling.

Oor die wenslikheid van die insluiting van 'n kernprogram met kulturele inhoude is die verskil in die onderwyspraktyke van verskillende lande gering. Alle lande aanvaar dan ook die wenslikheid van 'n kernprogram van kulturele inhoude wat doelbewus en doelgerig aangewend kan word vir die vorming van die leerling binne sy eie nasionale kultuur. Die leergange van die verskillende nasies verskil vanselfsprekend omdat daar verskille in historiese agtergrond en nasionale aspirasies is. Die verskille is egter nie beperk tot die kulturele inhoud van leergange nie, maar het ook betrekking op die leerplansame- 
stelling (of kurrikulumsamestelling). Dit blyk o.a. duidelik uit die verabsolutering van die natuurwetenskaplike metode by die Naturalisme en die prakties nuttige by die Pragmatisme. ("Everything is true that works").

In aansluiting by Stellwag ${ }^{18}$ ) kan ons by wyse van verdere toeligting tussen twee aspekte van psigiese vorming onderskei, naamlik:

(i) die geestesverrykende of materiële bestanddeel waardeur nuwe inhoude en waardes aan die gees verskaf word (dit waarna ons pas verwys het) en

(ii) die geesteskolende as suiwer formele of vormende bestanddeel.

Die keuse van leerstof waardeur die geestesfunksies (psigiese funksies) deur formele vorming diensbaar gemaak moet word vir meer algemene verrigtinge, hou ook verband met die lewensopvatting, en meer in besonder met die antropologie, wat gehuldig word. Dit gaan hier om die veelbesproke "transfer" ofte wel geestesoordrag.

Insigte in die geestesorganisasie van die mens, en die daarmee gepaardgaande aanvaarding of ontkenning van die oordraagbaarheid van die funksies, het deur die eeue groot invloed op die onderwys gehad. 'n Historiese terugblik toon dat die menslike gees, sedert dit van sy wesenlike funksie om te dink, bewus geword het, sonder ophou oor hierdie funksie besin het en daarmee saam het besinning oor sy eie waarde en wese saamgegaan. Oor die metafisiese oorsprong van die antitese tussen "gees" en "stof" en daarmee saam die antitese tussen empirisme en rasionalisme kan hier nie verder uitgewei uord nie, en ons volstaan met die enkele opmerking dat elemente van hierdie konflik vandag nog onderskei kan word in die twee teenstrydige rigtings wat die Anglo-Amerikaanse en die Vastelandse onderwys kenmerk.

Die psigologiese rigting (in besonder Herbart), wat uit die naturalistiese opvattings van Rousseau voortvloei, glo dat daar geen oordraagbare, algemene vermoëns bestaan nie. Vir Herbart bestaan geestesvorming daarin om die psige so 'n ryk moontlike appersepsiemassa te gee. Dit is duidelik dat hier nie sprake is van afsonderlike vermoëns soos geheue, verstand, ens. nie. Oordrag bly, om Allport ${ }^{19}$ ) se woorde te gebruik, beperk tot "responses to a single element which may be common to a number of otherwise varying situations". Hierdie leer lê, volgens 'n resente werk deur Keller, ${ }^{20}$ ) ten 
grondslag van die moderne Amerikaanse hoërskool met sy haas onbeperkte vakkeuse.

Die Würzburgse skool van die denkpsigologie het, in teenstelling met die Anglo-Amerikaanse rigting, oortuigende bewyse gelewer dat geestesoordrag wel plaasvind. Hierdie resultate van Oswald Külpe, Lindworsky en Selz is deur die Nederlandse pedagoog Kohnstamm op die leerproses toegepas om 'n nuwe benadering omtrent formele vorming in te lei.

Hierdie geesteswetenskaplike benadering met die daarmee gepaardgaande aanvaarding van die moontlikheid van oordraagbaarheid van funksies, beklemtoon weer die wenslik. heid van gekeurde leerstof en die beperking van die spesialiseringsmoontlikhede in die skool. Kohnstamm kon selfs beweer: „Het mag als een onbetwiste stelling gelden, dat onze huidige onderwijswetgeving en -organisatie beheerst wordt door bepaalde opvattingen over die ,vormende waarde'." 23)

Ons moet aanvaar dat die samestelling van die kurrikulum op didakties-pedagogiese beginsels berus en dat hierdie beginsels verband hou met die lewensopvatting wat die op. voeder huldig.

Om te differensieer ter wille van die individuele kind, beteken vir ons dan geensins dat aan al sy grille toegegee moet word nie, maar wel dat die onderwys moet berus op so 'n noukeurig moontlike bepaling van sy begaafdheid. Dit beteken ook nie, soos dit dikwels verkeerdelik vertolk word (die naturalistiese benadering), dat vir elke kind 'n spesiale kursus volgens sy aanleg en belangstelling voorsien moet word nie, maar eerder dat, ten einde die kind op te voed, die onderwyser moet probeer vasstel op watter wyse die beste vordering gemaak sal word in leerstof wat vir sy volwassewording noodsaaklik is en nodig is as voorbereiding vir sy taak as sedelike-selfstandige volwassene.

\section{(c) T.o.v. die hanteringsprinsipe (die leervorm)}

Dit kom soms voor of daar nie voldoende waarde geheg word aan didakties-pedagogiese beginsels wanneer daar in die praktyk oor onderuysorganisasie besin word nie. Ons sal vervolgens dus poog om enkele van hierdie beginsels toe te lig en wel t.o.v. gedifferensieerde onderwys in ' $n$ komprehensiewe hoërskool. Eerstens dan enkele opmerkings oor die komprehensiewe hoërskool. 


\section{Die komprehensiewe hoërskool}

Amerikaanse opvoedkundiges se aanspraak dat die komprehensiewe hoërskool 'n „peculiar American institution" is wat voorsiening maak vir onderwys ,in harmony with some deep-rooted American democratic beliefs" (Keller), berus o.a. op hulle oortuiging dat sosiale integrasie 'n noodsaaklike korrelaat vir enige demokratiese skoolorganisasie is. Keller ${ }^{24}$ ) lig dit verder soos volg toe: "The comprehensive high school aims to serve the needs of all American youth. That is to say it accepts without selection all the young people in the area it commands - all races, creeds, nationalities, intelligences, talents and all levels of wealth and social status".

Die Transvaalse komprehensiewe hoërskool daarenteen is alleen ten opsigte van die laasgenoemde vier aspekte komprehensief (intelligensie, talent, welvaart en sosiale status) Voortvloeiend uit ons lewensopvatting word byvoorbeeld aanvaar dat dit in S.A. wenslik is om in aparte skole vir onderwys van verskillende rasse, nl. Blankes, Indiërs, Kleurlinge en Bantoes voorsiening te maak.

Soos elke volk sy eie lewensopvatting het waardeur die lewe vir die lede van die volk sinvol gemaak word, eenheid verkry word en koers aangedui word, so word ons lewensopvatting in ons onderwysbeleid verwerk en is dit nie alleen in die skooltipe kenbaar nie, maar ook in die skoolorganisasie. Ook hier kies ons nou weer net 'n enkele voorbeeld vir toeligting, nl. die beoordeling van individuele verskille tussen leerlinge met die oog op seleksie en klassifikasie vir gedifferensieerde onderwys.

(i) Gedifferensieerde onderwys vir die kind as individu.

Geen twee mense is presies eenders nie, maar geen twee mense is totaal verskillend nie.

Daar is verskille tussen mense, wat vergelykbare verskille is, en juis in hierdie vergelykbaarheid is hulle weer gelyk. Die mens is eksemplaar en individu. ${ }^{25}$ ) Die universele (d.i. die algemeen-menslike of gemeenskaplike waarin alle mense deel) is wel die essensie van menswees, maar die partikuliere maak hom tot 'n besondere mens. ${ }^{26}$ )

Daar is diegene wat die mens sien as somtotaal van sy individuele eienskappe. Die persoonlikheid is dan hierdie 
eienskappe in ' $n$ bepaalde verhouding tot mekaar. Deur oorbeklemtoning van die individuele verskille ontstaan die behoefte dan om hierdie verskille steeds noukeuriger te meet. Hou noukeuriger elke faset gemeet kan word, hoe beter ken ons die mens, word daar dan geredeneer. Hierdie inhoudelike (biologistiese en psigologistiese) opvatting van die begrip individu lei dan verder tot naturalistiese toepassings daarvan in die onderwyspraktyk, waarna ons weldra weer sal verwys.

Die mens is geen somtotaal van sy eie kenmerkende eienskappe nie. Die mens is 'n vita varia et immensa vehementer het Augustinus reeds lank voor die opkoms van die wetenskaplike psigologie gesê, en dit is nog steeds waar. Ons kan sy grense nie aandui en sy diepte nie peil nie.

Die eienskappe van die mens kan net nie in 'n legkaart tot 'n eenheid saamgevoeg word nie. Dit blyk o.a. uit die verband tussen die psigiese en die sedelike, die twee fasette van die mens waarop die onderwys en die opvoeding onderskeidelik in besonder betrekking het.

Die sedelike is wel afhanklik van die psigiese. Sedelike karaktervorming vereis wel die harmonie van denke, gevoel en wil; van alle psigiese "vermoëns" van die mens. ${ }^{27}$ ) Maar die psigiese as sodanig is nie die kosmiese of "aardse" wesensgrond van die sedelike nie. In die van God gegewe aard van die sedelike lê sy kosmiese wesensgrond (Stoker). ${ }^{28}$ )

Die pedagogiek eis dus, naas die erkenning van individuele verskille, ook die erkenning van die sedelike gelykwaardigheid van die mensheid: nie 'n sedelike gelykwaardigheid in die sin van gelyke sedelike niveau nie (daar is verskille in eerlikheid, betroubaarheid, e.s.m.), maar in die sin dat elke mens in wese by magte is om 'n sedelike besluit te neem en hom daarvolgens te rig in sy gedrag..$^{29}$ )

Die psige of bewussyn met al sy psigiese funksies, is nie die enigste stukrag in die mens nie. Die mens is nie net 'n organisme wat deur gewoontevorming lewe nie; hy is nie net 'n wese wat hom gedurig aan die omgewing ,aanpas" nie.

Daar is oorvloedige bewyse dat hy bokant sy liggaam/ psige kan uitstyg en dat hy, vanweë sy geestelike dimensie wat hom tot ingrypende gewetensbeslissinge in staat stel, tot die hoogste waarde-skeppinge, soos o.a. beliggaam in die taal en kultuur, kan kom. ${ }^{30}$ )

Gedifferensieerde onderwys, gebaseer op verskille in begaafdheid, lei nie sonder meer tot gedifferensieerde opvoeding 
nie, want die begaafdheid is nie ' $n$ aanduiding van ' $n$ kwaliteit of kompleks van kwaliteite sonder waarde-erkenning nie. ${ }^{31}$ ) Ons aangesprokenheid en ons verantwoordelikheid spruit nie voort uit ons verskillende individuele biologiese en psigiese eienskappe nie. Dit is juis ' $n$ goddelike opdrag aan ons om ook van hierdie feitelike aspekte van ons menswees iets te maak Gedifferensieerde onderwys, wat op grond van individuele verskille ook in gedifferensieerde opvoeding omslaan, dit wil sê opvoeding wat alleen afhanklik is van individuele verskille en die daaruit voortvloeiende gewenste verskille in onderwysmetodes en leerstofinhoude, is strydig met ons Christelike lewensopvatting. ${ }^{32}$ )

\section{(ii) Seleksie en klassifikasie van leerlinge}

Dit is reeds duidelik dat die geesteswetenskappe t.o.v. meting en die aanwending van toetsresultate, onderskei moet word van die natuurwetenskappe. Die pedagogiek, as geesteswetenskap, moet binne die individuele nog onderskei tussen die partikuliere en die singuliere. ${ }^{33}$ ) Die objekte van tegniese, natuurwetenskaplike denke is partikuliere, d.w.s. eksemplare uit 'n soort-eenhede van 'n versameling wat volgens bepaalde prinsipes getel, geweeg of gemeet kan word, of wat minstens uit identiese elemente opgebou is.

Nou werk die statistiek wel met mense, met individue as partikuliere of as eksemplare. Maar die pedagogiek werk met die mens as 'n singulier, 'n unicum, 'n unieke persoon, wat „einmalig", onherhaalbaar en onvoorspelbaar is.

Die kenstruktuur van die natuurwetenskappe word uit kwalitatiewe en kwantitatiewe skeibare en meetbare rangordes opgebou. Die natuurwetenskappe werk dus met partikuliere objekte, maar die geesteswetenskappe werk met singuliere objekte wat in geestelike gemeenskap met mekaar verkeer. Juis om hierdie rede moet die geesteswetenskappe onderskei word van die natuurwetenskappe, waar ' $n$ middeldoel-verhouding vir 'n oorsaak $a$ altyd 'n gevolg $b$ veronderstel.

Uit 'n geesteswetenskaplike benadering is die mens nie voorspelbaarheid nie maar moonulikheid.

Kinders verskil (biologies, psigies en sosiaal) van mekaar omdat hulle verskillende eienskappe oorerf en omdat hulle onder verskillende omstandighede opgroei.

Deur psigiese „meting" word pogings aangewend om die 
verskille en ooreenkomste tussen kinders te bepaal. Hierdie verkwantifiseerde resultate dien dan om die absolute posisie van ' $n$ individu in verhouding met ander individue te bepaal, en soms word dit aangewend om die kind se toekomstige suksesse te vourspel en sy toekomstige beroep daarvolgens te bepaal.

Ons moet egter besef dat sodanige prognose wat op die kwantifisering van die mens berus, die fundamentele vergissing inhou dat die mens as mens meetbaar is. Die oorweldigende getal empiriese bewyse ${ }^{34}$ ) dat daar 'n relatief lae korrelasie bestaan tussen individuele begaafdhede, beroepskeuse en beroepstevredenheid lewer treffend bewys van die naturalistiese misvatting waarop sodanige aanwending van die resultate van psigiese "meting" berus. Die resultate van psigiese „meting" kan betekenisvolle hulpmiddels wees vir die seleksie en klassifikasie van leerlinge en dit kan nuttige hulpmiddels wees vir die skoolorganisasie, omdat dit wel 'n aanduiding gee van sekere psigiese moontlikhede van leerlinge, maar dit mag nie beslissend wees vir sy beroepskeuse nie. Dit mag, wat beroepsoriëntering betref, alleen as hulpmiddel deur die volwassene aangewend word om "die jeugdige in hierdie situasie in sekere bane te lei sodat hulle saam denkend en handelend kan besluit oor watter weg die beste is om te volg". ${ }^{35}$ )

Aan hierdie vereiste voldoen die Transvaalse Onderwysdepartement deur te bepaal dat enige leerling wat dienooreenkomstig presteer van een baan (of kursus) oorgeplaas kan word na 'n ander. Dit is nou die verantuoordelikheid van elke skool om dit prakties moontlik te mak.

(iii) $O p$ wie berus die verantwoordelikheid om ' $n$ beroepskeuse vir'n leerling te doen?

Die roepingsbewuste onderwyser aanvaar dat dit sy verantwoordelikheid (in aanvullende ouerskap) is, om steun en hulp te verleen aan die nie-volwassene. Dit vereis simpatieke dog strenge gesagsleiding, aangesien hy in die onvolwassene se vermoëns en omstandighede geleenthede tot iets, of sterker gestel, verpligtinge tot iets sien.

Saam met sy verantwoordelikheid om toe te sien dat die kind sy potensialiteite op 'n verantwoordbare wyse ontwikkel, aanvaar hierdie opvoeder dat hy die finale verantwoordelik- 
heid vir die kind se psigiese ontuikkeling, en daarmee saam sy keuse van ' $n$ beroep, asook die keuse van die geskikte keusevakke wat daarvoor nodig is, op die kind self moet plaas. Dit spruit voort uit sy visie op die persoonlikheid, naamlik, dat wat die mens met die komponente van sy sielkundige karakter gaan maak, vanuit die geestelike kern van die persoonstruktuur bepaal word. ${ }^{36}$ )

Dit sou die organisasie van die skool oneindig vergemaklik as ons die leerling se beroep kon bepaal deur sy kapasiteite te meet. Maar ons moet aanvaar dat al die mens se kapasiteite nie ten volle ontwikkel kan word nie; en aangesien dit nie in dieselfde mate vir sy lewenstaak essensieel is nie, moet hy 'n keuse maak. Ons kan dus saam met $B i j{ }^{39}$ ) konkludeer: „Onze levenstaak dient niet om onze capaciteiten te ontplooien, maar onze capaciteiten ontplooien wij om onze levenstaak te vervullen". Die taak is primêr.

Die noodsaaklikheid van verantwoordbare beroepsoriëntering kan nie oorbeklemtoon word nie. Maar die beroepsoriënteur moet onthou dat die leerling se keuse van 'n geskikte beroepsrigting nie alleen op grond van resultate wat hy behaal in psigiese of skolastiese toetse, of die eise van die maatskappy, bepaal word nie. Dit moet resultaat wees van 'n eie stellingname, en die uitgroei na beroepsvolwassenheid moet lei tot die selfverantwoordelike selfbepaling tot 'n beroep. ${ }^{40}$ ) Die beroepsoriënteur se taak is dus primêr 'n pedagogiese taak. Hy moet die kind opvoed om met dankbaarheid vir die gawes wat hy ontvang het, sy eie taak en die vakke wat daarvoor nodig is te aanvaar. Vorming vir 'n beroep is immers nie in die eerste plek die aanleer van tegniese vaardigheid of wetenskaplike kennis nie, maar die verwerwing van karakterkwaliteite wat 'n beroepsverantwoordelikheid wek en tot beroepsbekwaamheid en beroepstevredenheid lei.

Ten slotte ontstaan die vraag na die verband tussen seleksie en prestasie.

(iv) Differensiasie en die eise wat aan 'n leerling gestel word

Aangesien daar verskille tussen kinders is, sou dit onverstandig van die opvoeder wees om alle kinders op dieselfde manier te onderrig. Van hom wat vyf talente ontvang het, kan 
meer verwag word, en moet meer verwag word, as van hom wat een talent ontvang het (Matth. 25). Die onderwys moet rekening hou met hierdie verskillendheid en ongelykheid. Maar ons moet byvoeg: Van hom wat vyf talente ontvang het, word verwag om dit met honderd persent te vermeerder, en van hom wat een talent ontvang het, word ook verwag om dit met honderd persent te vermeerder. Elkeen moet volgens sy vermoë sy maksimum lewer. Daar is geen differensiasie t.o.v. die kind se verantwoordelikheid nie.

Die onderwys moet rekening hou met die verskille in die ontwikkelende aanleg van kinders. Maar die aard van die steun wat verleen word, word nie deur die geërfde faktore alleen bepaal nie. Die opvoeder se steungewing moet verantwoordbaar en doelgerig wees. Gedifferensieerde onderwys sluit dan ook veel meer in as ,aanpassing" van die onderwys by die kind se vermoëns; dit beteken meer as net differensiasie van leerstof, leermetode en onderwysmetode. Dit raak ook die kwessie van die eise wat aan 'n leerling gestel word, en daarmee val saam die praktiese vraagstukke van bevordering, klassifikasie, dissipline en dergelike meer.

Dit is dus die didakties-pedagogiese taak van die skool om die kind op te voed om op eie verantwoordelikheid sy optimale prestasie te lewer. Leerlinge moet voor die keuse gestel word om 'n hoër prestasiegroep (baan) te verower. Dit veronderstel weer periodieke prestasie-groepering in plaas van 'n naturalisties-meganistiese aanwending van die resultate van psigiese meting.

Die Transvaalse Onderwysdepartement se standpunt, naamlik dat die skoolprestasie die belangrikste kriterium vir homogene klassifikasie van leerlinge bly, ${ }^{41}$ ) kom vir ons kerngesond voor. Die toepassing van hierdie didaktiese beginsel in die praktyk is dan ook opgawe vir elke hoof en elke onderwyser.

\section{Opsommend:}

Om op te som kan ons beweer dat skoolopvoeding, in teenstelling met opvoeding in die algemene sin van die woord, veronderstel dat die onderwyser-opvoeder teoretiese kennis sal hê van die doel van die opvoeding, die opvoedbaarheid van die kind, die middele en die metodes van opvoeding en dat hy 
kennis sal hê van die verwerkliking van hierdie beginsels in die praktyk.

ln ons moderne gekompliseerde lewe word die behoefte aan die bedenking, beplanning en sistematisering van die opvoedingsmiddele, m.a.u: die beheersing en uitbouing van die didaktiek, steeds groter en verdien dit 'n steeds belangriker plek in ons onderwys.

Duidelike onderskeiding van didakties-pedagogiese beginsels wat mede resultate is van ons eie lewensopvatting, is ' $n$ dringende behoefte in ons onderwys, ook by onderwysersopleiding.

Potchefstroom.

J. H. Jooste.

\section{BRONNEVERWYSING:}

1) Oberholzer, C. K.: Die pedagogiese. Herdruk uit Extra Mura, 1960, p. 1.

2) Skeat: Concise Etymological Dictionary of the English Language, p. 117 and p. 590.

Schreuder: Didactiek, in Paedagogische Encyclopaedie deur Verheyen en Casimir, p. 355.

3) Du Plessis, P. J. J.: Pedagogiek as Wetenskap, p. 62

4) Kyk Kohnstamm, Ph.: Keur uit het Didactisch werk, p. 63.

5) Van Gelder, L.: Vernieuwing van het Basisonderwijs, p. 1.

6) Van der Stoep, F.: Pedagogiese Grondslae van die Nuwere Didaktiek. Referaat gelewer tydens die 25-jarige jubileum van die Fakulteit Opvoedkunde, U.P., 22 Junie 1962.

7) Kyk Nel, B. F.: Die Aard en Wese van die Sielkundige Pedagogiek, p. 15.

8) Langeveld, M. J.: Algemene en Speciale Didactiek en het leren in het verband der Didactiek beschouwd. Paed. Studiën, Juli/Augustus 1959 , p. 339.

9) Kyk van Staden, J. L.: Opvoedkundige Teorie en Praktyk in die Transvaal gedurende die Jare 1900-1950 as die weerkaatsing van die Rigtinge van Lewensopvatting, p. 327.

10) Schutte, B. C.: Die Objektiwistiese en die Fenomemologiese Benaderings in die Empiriese Opvoedkunde. Bylae tot Koers, Maart 1960 , p. 1.

11) Coetzee, J. Chr.: Die Opvoedkunde, Bylae tot Koers, Feb. 1954, p. 3.

12) Bingle, H. J. J.: Die terrein van die Empiriese Opvoedkunde. Inougurele Rede.

13) Kyk Nel, B. F.: Die aard en wese van die Sielkundige Pedagogiek. Publikasies van die Universiteit van Pretoria, Nr. 2, p. 12.

14) Kyk Mulder, J. J.: Die aandeel van die Lewensopvatlike in die Proses van Opleiding van die Opvoeder-Onderwyser, p. 4.

15) Kyk Schoeman: Die antropologies-personologiese denkbeelde van die Derde Weense Skool en die betekenis hiervan vir die opvoeding in sedelike verband, pp. 134-138. 
16) Van Zyl, P.: Die antropologies-personologiese opvattinge van $F$.W. Foerster met nadruk op die eties-pedagogiese momente daarin, p. 36.

17) Van Zyl, P.: a.w., p. 131.

18) Stellwag, H. W. F.: De Waarde der Klassieke Vorming, p. 74. Kyk ook Nel, B. F.: Die Problematiek van die Vormende Waarde, p. 4.

19) Allport, G. W.: Personality, p. 259

20) Keller, F. J.: The Comprehensive High School, p. 11.

21) Nel, B. F.: Die Problematiek van die Vormende Waarde, p. 20.

22) Kyk Conant, J. B.: The American High School, p. 113 e.v.

23) Kohnstamm, Ph.: Keur uit het Didactisch Werk, pp. 7-8.

24) Keller, F. J.: The Comprehensive High School, p. 31.

25) Kyk Duijker, H. C. J. e.a.: Gelijkheid en Ongelijkheid bij de Mense, pp. 7-15.

26) Kyk Gunter, C. F. G.: Opvoedingsfilosofieë, p. 375.

27) Kyk Stoker, H. G.: Die Grond van die Sedelike, p. 17.

28) Stoker, H. G.: a.w., p. 13.

29) Langeveld, M. J.: Beknopte Theoretische Paedagogiek, p. 64.

30) Kyk ook Nel, B. F.; Sonnekus, M. C. H.; Garbers, J. G.: Grondstae van die Psigologie, p. 7.

31) Kyk Waterink, J.: Begaafdheid als kwalificatie der persoonlikheid. Algemeen Nederlandsch Tijdschrift voor Wijsbegeerte en Psychologie, Dec. 1948.

32) Oberholzer, C. K.: Moderne Persoonsvisies, pp. 58-59.

33) Langeveld, M. J.: Verkenning en Verdieping, p. 233.

34) Kyk Super, D. E.: Appraising Vocational Fitness by means of Psychological Tests, p. 484.

Sanderson, H.: Basic conceptions in Vocational Guidance, pp. 16-17.

35) Landman, W. A.: 'n Antropologies-pedagogiese beskouing van Beroepsoriëntering, p. 25.

36) Kyk Oberholzer, C. K.: Moderne Persoonsvisies, pp. 58-59.

37) Kyk Beets, N.: De Grote Jongen, p. 12

38) Beets, N.: a.w., p. 21.

39) Bijl, J.: Inleiding tot de Algemene Didactiek van het Basis-onderwijs, p. 33.

40) Schomaker, J. A.: Beroepsbepaling en Opvoeding, p. 201

41) van Wyk, A. H. du P.: Promotion in School: Bulletin Nr. 3, Sept. 1957, p. 152. 